\title{
THE NEW ZEALAND DAIRY MANUFACTURING INDUSTRY
}

\author{
Jocelyn Gibson \\ Waikato University
}

The dairy industry processes milk and cream to produce cheese, butter, processed milks, milkpowder and infant food. ${ }^{1}$ It is not involved with domestic milk production or ice cream production. It is highly intemationalised and heavily dependent on the global market for its survival.

New Zealand produces $1.5 \%$ of total global dairy product. $90 \%$ of that output is exported - our closest rival in terms of the proportion of output exported is Australia, with $30 \%$. That $90 \%$ contributes $25 \%$ of the supply of dairy products in the world market. So, New Zealand supplies one quarter of the $5 \%$ of total global output which is traded.

The world market is highly competitive and small fluctuations in world output have large effects on supply and demand, and therefore on the world price. Many of New Zealand's competitors are protected or subsidised. The New Zealand industry is very much a price taker.

In this trading environment the industry is extremely vulnerable and industrial disputes are very damaging. In 1989 a major dispute resulted in $\$ 22$ million worth of milk going down the drain and further losses of $\$ 26$ million through damaged markets and penalties. Such losses could not be sustained as a regular feature of wage negotiations. It was clear that losses of such magnitude would have a negative impact on both employment and wage levels in the long term. Ultimately it was a no-win situation.

The industry had changed substantially in the last two decades, going from around 100 companies in 1970 to only 16 in 1992; Table One. Automation had heralded a move to larger, more technological plants, with only 34 plants operating today, compared to 103 in 1978. Output per worker had increased by $40 \%$ since 1978 , due to both a reduction in the number of workers and an increase in the level of output. At the same time the industry had moved toward more differentiated products of a higher quality.

Automation had changed the nature of the workforce demanded by the industry. Predominantly manual, narrowskilled jobs were replaced by highly skilled jobs. Workers' skills and responsibilities had both broadened, to the extent that fewer workers controlled a wider section of the production line, and deepened, as workers needed to understand both the manufacturing process and the automation which controlled that process.

The Dairy Industry Manufacturing employers and the Food and Textile workers' Union were faced with a choice. one option was to continue with the congrontational style of industrial relations. This would potentially drive the industry into producing only low quality, low priced products, such as stock food. For workers that would mean

Table 1 Changes in employment and output 1978 to 1990

\begin{tabular}{|c|c|c|c|c|}
\hline Year & 78-79 & 1981-82 & 1987-88 & $1989-90$ \\
\hline $\begin{array}{l}\text { Persons employed } \\
\text { (full-time equivalents) }\end{array}$ & 7558 & 7603 & 6416 & 6334 \\
\hline Output (000 tonnes) & 698 & 758 & 830 & 815 \\
\hline $\begin{array}{l}\text { Output per employee } \\
\text { (tonnes) }\end{array}$ & 92.3 & 99.7 & 129.3 & 128.7 \\
\hline Percentage change & - & +8.0 & +29.7 & -0.5 \\
\hline Percentage change from 1978-79 & - & +8.0 & +40.1 & +39.4 \\
\hline
\end{tabular}


low wages and low skills. The alternative was for the parties to take a more co-operative and consultative approach to the future. This way the industry could produce high quality products which attract high prices internationally. Such an industry would need highly skilled workers, and pay higher wages.

\section{Memorandum of Understanding}

A negotiated solution was found by way of the Memorandum of Understanding which set out a programme for restructuring in the industry. An immediate benefit for employers was the ability to enter into site by site agreements on hours of work and rosters. The issue of increased flexibility had been a central bone of contention during the dispute.

In 1989 the challenge was to acknowledge the skill levels demanded by the industry, and recognise the crucial role skilled workers would play in its future. The way ahead lay in quality production of high value products, process and product innovation, and flexibility, both of the work process and of outputs. All of which depend on the involvement of workers, particularly highly skilled workers.

The unions' stated objectives in signing the Memorandum included promoting an industry which survives and prospers by maximising onshore value added opportunities and ensuring worker participation in the day to day management of the industry. The Memorandum delineates a five step process: climate setting; process analysis; job redesign; skills analysis; and training needs analysis. All of this is to be carried out within a framework of management/union consultative committees.

Central to the restructuring is the move to a skills based pay system, away from the existing broad occupational levels. Under this system workers will be paid according to the skills they are competent in and which they use in their job. This involves identifying all the skills used in the industry (so far they have come up with over 2000). By identifying workers skills the opportunity is created to clearly define, and meet, the training needs of the industry. An obvious extension of this is the development of an industry training programme.

At this stage, neither the National Consultative Committee, which is driving the process, nor the Project team, who are doing the job analysis and design, know how it will work in the end. The complexity of the proposal under negotiation goes beyond that attempted elsewhere in New Zealand or overseas. This hopefully bodes well for the effectiveness of the final design, but in the meantime creates a problem in terms of feedback and information dispersion around the industry. The initial time frame anticipated full implementation by December 1992. To date the skills analysis is still incomplete.

\section{Implications}

The restructuring, with the move to greater worker participation, has ramifications for factory management. Workers, being more highly skilled and with appropriate training, will be able to take a higher degree of responsibility for the running of the plant. They will be more involved in problem solving and decision making on the factory floor.

One manager talked about giving workers more "ownership of the production process". Within moments he was also talking about reducing labour costs, and the possibility of removing the need for middle management. The intention is to have a single collective contracı covering all workers in the industry. So there is the expoctation, among both managers and workers, that uradiuonal demarcations between occupations will be brohen down. This is not so much multi-skilling, in the senve that everyone will be able to do all jobs in the facton. hut crissskilling in that fitters or electricians will be truncd in the operators. The aim is to ensure every possitic wis is covered by at least one person during each shift For example, having an electrician/operator means if an electrical problem arises there is someone with the appropriate training on hand. There is no need for an expensive call out. Both wage costs and the loss of production time are reduced.

The employer expects to profit from this programme through reduced costs and greater product consistency and quality. The workers see benefits from greater job security and the development of a clear career structure based on training and skills.

Discussion of the restructuring has an emphasis on cooperation and consultation between employers, managers, unions and workers. This represents a substantial shift in attitudes from the confrontational relationships of the past. The process is about changing the way people relate to each other, the way they view their jobs and the people they work with. These changes do not come about just by rewriting the rules.

The people involved are not an homogenous group of individuals who will react and change in the same way. Each factory has its own distinct dynamic, which includes internal politics and social relations. For example, one site has a site consultative committee in place as a result of an independent initiative at that factory some years ago. They are already well down the reform path. Each site will develop at its own pace, and the roles of manager, site consultative committee member and union delegate become pivotal to the success of the reforms.

Notably, a large proportion of the consultation to date has occurred at a very senior level. Union officials consult with industry employer representatives. While there is a good flow of information out through the union network, managers receive very little by way of progress reports. 
Site consultative committee members have had some training about their role in the process, but the uneven development of the sites may cause problems in the future. The further out from the consultative core people are the weaker the degree of understanding about the reforms and their objectives. One young worker believes the process is all about putting everybody onto individual employment contracts.

The success of the process may depend on ensuring that everyone understands and supports the changes. The process may be about "empowering" workers by denying them the choice to just "go with the flow" and pick up their pay packet at the end of each week. A key concept is "worker involvement" or "worker responsibility". It is linked with upskilling, it is linked with innovation, it is linked with reducing unit costs, it is linked with quality product. The question yet to be answered is in whose interests these links are made; the farmers, the workers, the managers or some or all of these groups.

\section{Summary and Conclusions}

The dairy manufacturing industry is heavily dependent on its international markets. The ability to meet the requirements of overseas customers is paramount. In 1989 a major pay dispute cost the industry $\$ 48$ mill, including lost customers and penalties. The union and the employers realised that a co-operative approach to industrial relations was needed for the future. A negotiated agreement set out a programme for job redesign and skills analysis. Central to the plan is the replacement of the occupational wage structure with a skills based pay system. A corollary is the commitment to worker training. At this stage, the task of skills analysis is not yet complete.

The reorganisation process has been extended well beyond its original deadlines. There is still a lot of uncertainty about the final outcomes. Anticipated results include an increasing degree of worker control of the production process and a breakdown of traditional occupational demarcations, as workers become increasingly skilled. A key concept is "worker involvement" or "worker responsibility". Both the union and the employers expect positive effects on industry profitability.

The uncertainty means communication between the national level of the project and individual sites is very important. Each site has its own dynamic and is moving through the restructuring process in its own way. Pivotal to the success of the restructuring process is the ability and willingness of all participants to understand, accept and support the changes. The process of workplace change in the dairy manufacturing industry is extremely complex. The changes are not clearly defined and the outcomes are largely speculative. It is not possible to determine ex ante the full impact of the reforms on such matters as productivity, output, labour demand, efficiency, profitability or manager-worker relations. The expectations are that the results will be positive, but much of the success of these reforms will depend on the ability and willingness of people at all levels of the industry to make changes. That is underpinned by their understanding and acceptance of the objectives of workplace reform in the dairy industry.

\section{Future Research}

A number of tenative questions result from the work to date. For example, why do employers choose to participate in workplace reform? Does workplace reform give workers more control, democratic or otherwise, over the production process? Is workplace reform feasible only in industries which employ a skilled fulltime workforce, or can the same principles be applied in industries where a high proportion of part-time, casual or temporary workers are employed?

\section{Note}

1. This paper reports the first part of a work for a Masters thesis in Economics. The thesis is a qualitative case study of workplace changes in the New Zealand Darry Manufacturing industry. As a work in progress repon this paper describes the key changes in the industry and considers some of the issues which have arisen through the fieldwork.

\section{References}

Department of Statistics 1991 Business Activity Statistics Department of Statistics

Department of Statistics 1983 Census of Manufacturing 1981-82 Department of Statistics

Department of Statistics 1987 Economy Wide Census, Manufacturing Department of Statistics

Enderwick,P. 1992 Workplace Reform and International Competitiveness: The New Zealand Case (unpublished).

Kanawaty, G., A. Gladstone, J. Prokopenko, G. Rodgers, 1989 Adjustment at the micro level International Labour Review : 269-296.

New Zealand Dairy BoardNew Zealand Dairy Board Background and Perspectives 1988

New Zealand Food and Textile Workers Union 1991 Bargaining Strategy in the New Zealand Dairy Industry

New Zealand Dairy Board Annual Reports 1980, 1983 , 1990, 1991

Tolich, P. 1991 Dairy Industry Joint Education Programme 1991 Paper presented to the Union/ Tertiary Research Conference, Victoria University, June 1991 